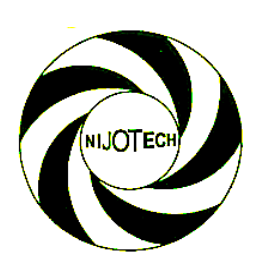

Nigerian Journal of Technology (NIJOTECH)

Vol. 38, No. 3, July 2019, pp. 566 - $\mathbf{5 7 2}$

Copyright@ Faculty of Engineering, University of Nigeria, Nsukka,

Print ISSN: 0331-8443, Electronic ISSN: 2467-8821

http://dx.doi.org/10.4314/njt.v38i3.4

\title{
ASSESSMENT ON BUILDING MAINTENANCE IN NIGERIAN UNIVERSITIES: A CASE STUDY OF UNIVERSITY OF ILORIN
}

\author{
S. O. Odeyemi ${ }^{1,}{ }^{*}$, O. I. Adeniyi ${ }^{2}$ and A. I. Amoo ${ }^{3}$ \\ 1, Department of Civil Engineering, KWARA State University, Malete, KWARA State, NIGERIA \\ 2, DEPARTMENT OF STATISTICS, UNIVERSITY OF ILORIN, ILORIN, KWARA STATE, NIGERIA \\ 3, WORKS DEPARTMENT, UNIVERSITY OF ILORIN, ILORIN, ILORIN, KWARA STATE, NIGERIA \\ E-mail addresses: ${ }^{1}$ samson.odeyemi@kwasu.edu.ng, ${ }^{2}$ adeniyi.oi@unilorin.edu.ng, \\ 3 salau.ai@unilorin.edu.ng
}

\begin{abstract}
Building maintenance comprises the preservation of buildings to retain their durability and economic values. It is a significant aspect of facilities management that necessitates planning. This research studied the effect of factors such as lack of maintenance policy, inadequate provision of funds for maintenance, etc, on building maintenance in the University of Ilorin. The field assessment focused on the staff residential quarters, staff offices, lecture rooms and students' hostels. Questionnaires were administered and analysed to determine how these factors affect maintenance in the University. The results reveal that students, who are the main users of the hostels and lecture theatres believe that all the factors considered significantly contribute to maintenance failure in the University while the staff believe that change of government significantly affect maintenance in the University. It is recommended that good maintenance policies should be drawn by the University to ensure constant and regular maintenance of the infrastructures.
\end{abstract}

Keywords: University of Ilorin, Maintenance, Staff quarters, Staff offices, Lecture theatres, Students'hostels.

\section{INTRODUCTION}

Infrastructures constitute a huge percentage of a country's investment. It is important that these facilities, which include public buildings, are well maintained for them to serve the aesthetical and architectural purposes for which they are constructed [1]. A major peculiarity of a developed country is their infrastructural development with well planned maintenance since this plays a major part in the socio-economic growth of any country. Consequently, a lot of developed nations have well maintained infrastructures which they hang on as a source of income for their economy. Hence, such nations take maintenance of their infrastructures seriously and use them to attract tourists to their country to yield revenue for them $[2,3]$.

Several Asian and European nations have countless developed educational institutions with sufficient infrastructures which make a lot of Nigerians throng into those countries, spend huge amount of money to be educated [2]. However, regular maintenance has been a challenge in Nigerian institutions due to reasons such as corruption, poor funding, bribery and improper use of facilities by occupants $[4,5]$. There are many construction projects in Nigeria worth a lot of money. This necessitates that construction management practices be given serious attention to prevent adverse effect on the infrastructures.

University structures need to be maintained to ensure a favourable environment that inspires innovative teaching, learning and research [6]-[8]. However, authorities seem to be concerned about constructing new structures while old ones are left to be destroyed [9], [10]. The quality and aesthetics of buildings and infrastructures that exist in an institution of learning

${ }^{*}$ Corresponding author, tel: + $234-805-414$ - 7596 
will, to a far extent, reflect her image in terms of aesthetics, architectural excellence and services [11]. It was opined by $[12,13]$ that the condition of most public buildings in Nigeria is very poor and in most cases beyond repair. Despite huge amount of money expended in constructing such buildings, they are abandoned, once they are commissioned, to experience premature but steady and rapid dilapidation, decay and deterioration.

Maintenance is defined as the sequence of events carried out to take care of a structure and to guarantee the intended functions and optimal performance of a structure's life cycle [14]. BS 3811 (1993) [15] defined 'Maintenance' as "the combination of all technical and administrative actions, including supervision actions, intended to retain an item in, or restore it to a state in which it can perform a required function. Maintenance was also defined by [10] as the blend of every activities carried out to retain an item in or restore it to a satisfactory condition. Maintenance brings about improved utilization of buildings, ensuring the highest safety standards. However, building maintenance is costly both from financial and environmental perspectives [14].

Ojara $[16,17]$ reported that dilapidation of public structures could be caused by increase in the cost of building maintenance and poor government policies. Nurul and Md Azree [18] submitted that defective materials and poor workmanship are causes of infrastructural decay.

Many public structures are not well maintained. The components of such buildings such as floors, ceilings, doors and windows frequently express evidence of nonexistence of maintenance and repair. Some office and residential buildings of public institutions have not experienced any major maintenance since they were constructed. This has resulted in such structures being in a dilapidated state and some of them have been totally abandoned. Thus, lack of maintenance of these facilities by occupants and authorities regularly results in the reduction of the lifespan of such buildings [19].

In view of the above, this research is aimed at assessing the building maintenance at the University of Ilorin, Ilorin, main campus. The buildings assessed include the office buildings, the students' lecture rooms, the students' hostels and the University staff quarters.

\section{METHODOLOGY}

University of Ilorin, located in Ilorin, Kwara State, Nigeria, was established in 1975 . It currently has a student population of over 50,000 and a staff strength of about 500 . The University has 15 faculties offering several academic programmes.

The questionnaires designed for this research was structured to ensure that appropriate variables that define the scope of the research were captured. The variables include demographic data on respondents and factors that relate with aspects of maintenance as they affect structural health of buildings. Another subsection of the questionnaire produced information on maintenance of building by parts in suitable levels of details. Structured open-ended questions were considered and included to provoke responses from respondents during interviews. A sample of the questionnaires used in this research is shown in the Appendix.

Fifty (50) questionnaires each were distributed to the Staff Offices, Hostels and Staff Quarters, while seventy one (71) questionnaires were distributed to the Lecture rooms. Forty eight (48) questionnaires were returned out of fifty (50) for staff offices, forty eight (48) for Hostels, forty nine (49) for Staff Quarters and seventy one (71) returned for the Lecture rooms. Thus, a total of Two hundred and twenty one (221) questionnaires were distributed among the offices, hostels, staff quarters and lecture rooms of the University and Two hundred and thirteen (213) questionnaires were returned for analysis. This shows a response rate of $96.4 \%$.

Statistical Package for the Social Sciences (SPSS) software was used for analysing the data collected. In analysing the data collected from the questionnaires, the tabular and graphical presentation was employed for the qualitative analysis while the Chi-square test of independence was used for the quantitative analysis.

A test of independence of the responses gotten was carried out using the following statement hypothesis: $\mathrm{H}_{0}$ : The respondent responses are independent of the different University buildings

$\mathrm{H}_{1}$ : The respondent responses are dependent of the different University buildings

Significance level $\alpha: 0.05$

The Test Statistic adopted is shown in Equation 1:

$$
X^{2}=\Sigma \Sigma \frac{\left(O_{i j-E_{i j}}\right)^{2}}{E_{i j}}
$$


Where $O_{i j}$ is the observed frequency of responses for the ith grading and the $j_{\text {th }}$ University building; $E_{i j}$ the expected frequency of responses for the ith grading and the $j_{\text {th }}$ University Building. The Decision Rule is Reject the Null Hypothesis $\mathrm{H}_{0}$ if the P-value is less than the significance (0.05).

\section{RESULTS AND DISCUSSION}

\subsection{Data Output}

Figures 1 to 10 show the graphs of the responses from respondents on the effect of the following factors on maintenance at the University of Ilorin: lack of maintenance policy, inadequate provision of funds for maintenance, lack of experienced and welltrained building maintenance Engineers, overcrowding, untimely response to maintenance request, poor maintenance work done by the maintenance unit of the institution, corruption, misuse of facilities by occupants, poor architectural design and change of government. The results reveal

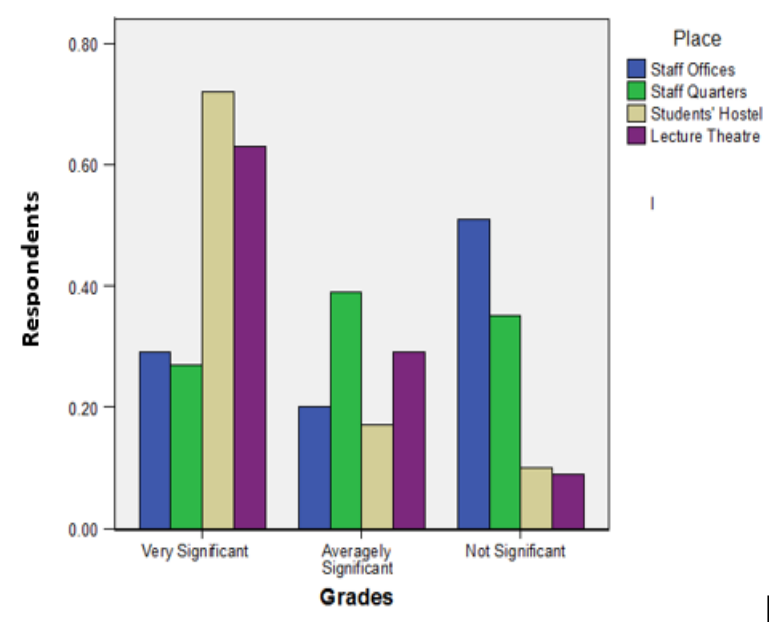

Figure 1: Responses on lack of maintenance policy

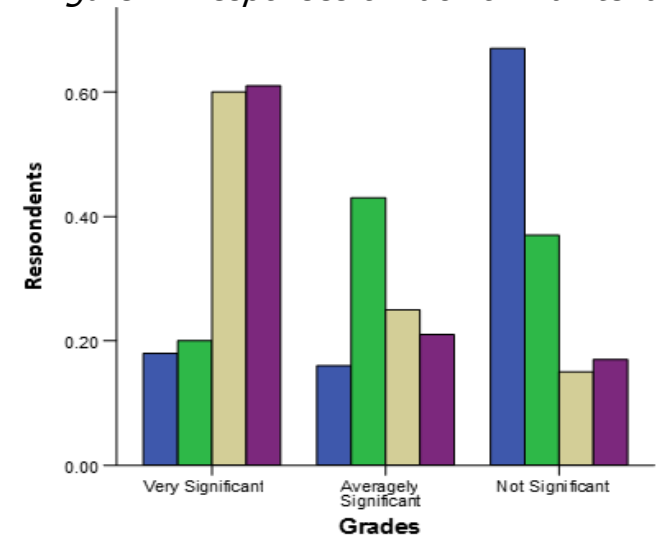

Figure 3: Responses on lack of experienced and welltrained building maintenance Engineers that all the factors considered contribute to maintenance failure in the University.

Students who are the main occupants of the Hostels and users of the Lecturer theatres were of the opinion that lack of maintenance policy, inadequate provision of funds for maintenance, lack of experienced and well-trained building maintenance Engineers, overcrowding, untimely response to maintenance request, poor maintenance work done by the maintenance unit of the institution, corruption, misuse of facilities by occupants, poor architectural design were significant factors on the University building maintenance as their responses on the significance of these factors were higher than the staff responses as shown in Figures 1 to 9. On the other hand, the responses of staff on the change of government as a factor was higher compared to that of the students as shown in Figure 10. The Staff also believe that corruption also has a significant effect on the poor maintenance of their offices.

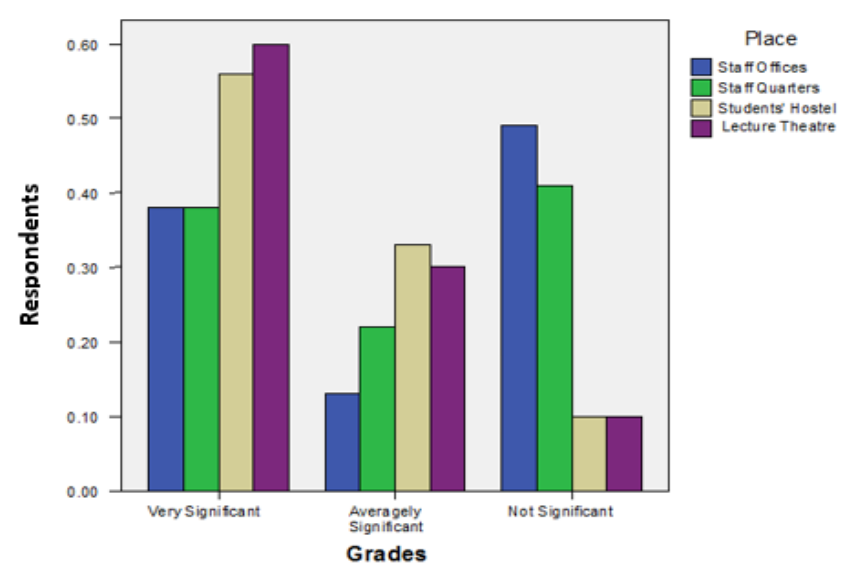

Figure 2: Responses on inadequate provision of funds for maintenance

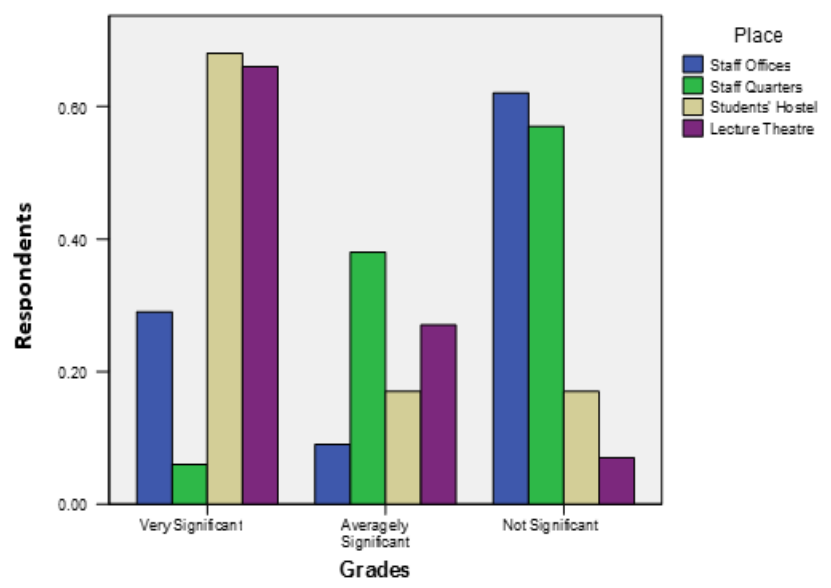

Figure 4: Responses on overcrowding 


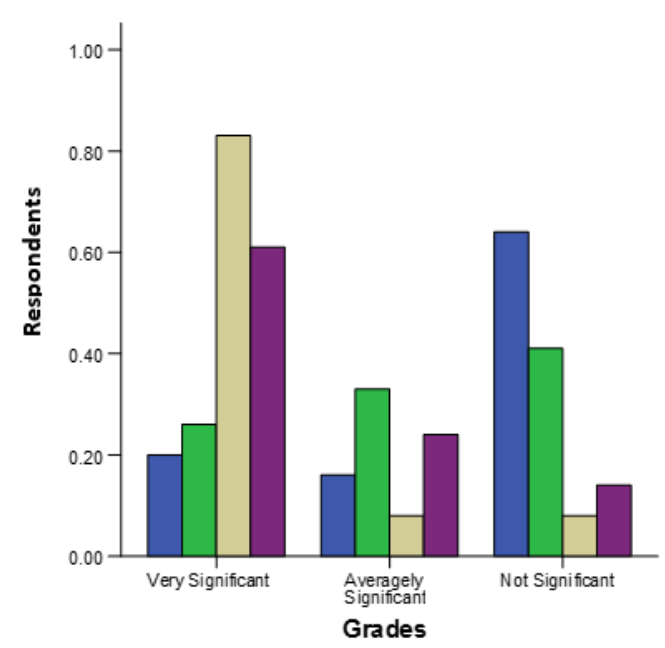

Figure 5: Responses on untimely response to maintenance request

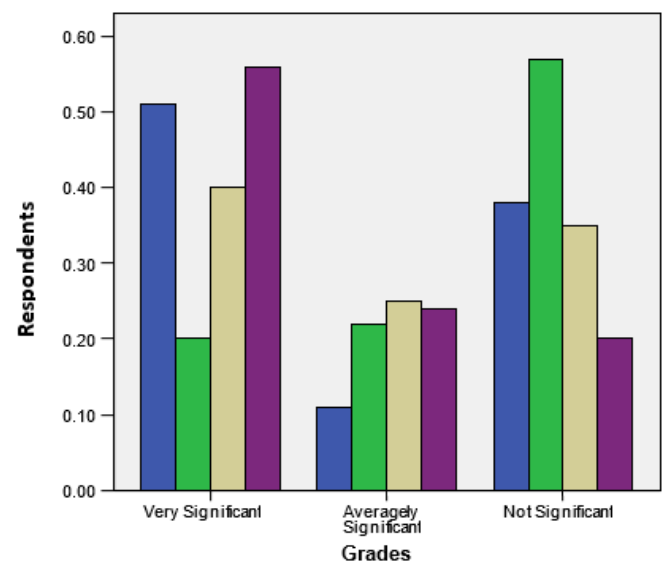

Figure 7: Responses on corruption

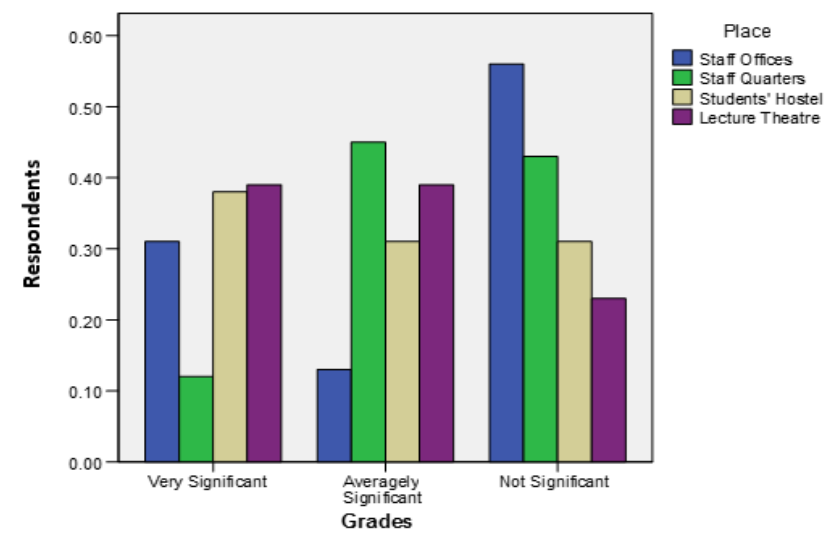

Figure 9: Responses on poor architectural design

\subsection{Test of independence of the respondents responses on the factors that affect the maintenance of the university buildings}

The Chi-square and P-values obtained are shown in Table 1. The P-Value for all the factors considered are less than 0.05 which was set as the significance level for the test of independence. In view of this, the null hypothesis $\left(\mathrm{H}_{0}\right.$ : The respondent responses are

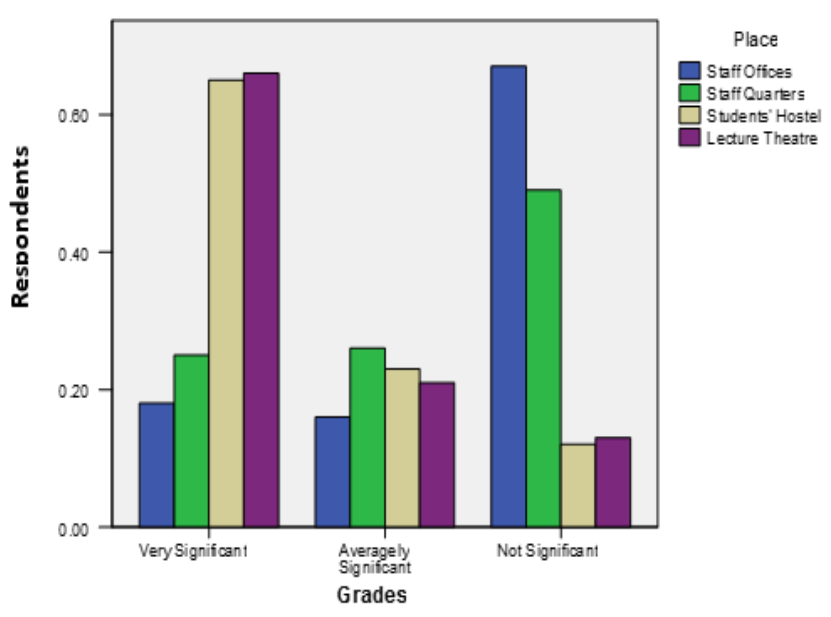

Figure 6: Responses on poor maintenance work done by the maintenance unit of the institution

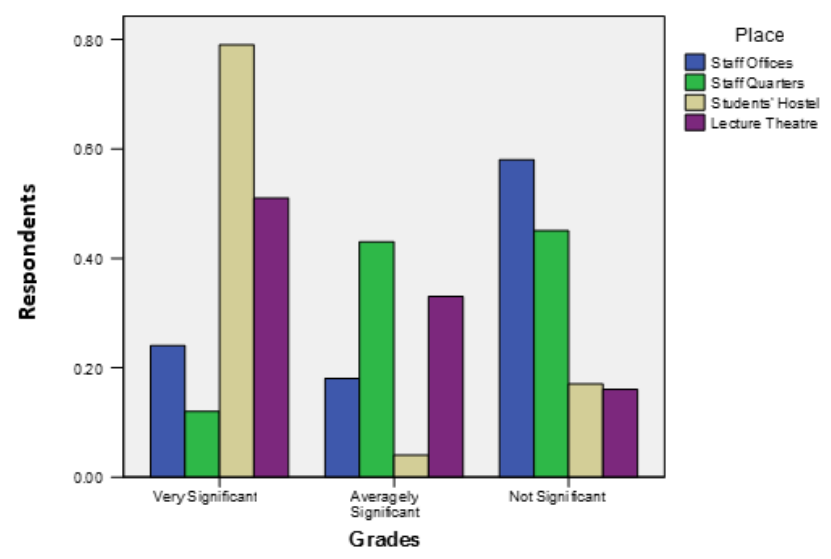

Figure 8: Responses on misuse of facilities by occupants

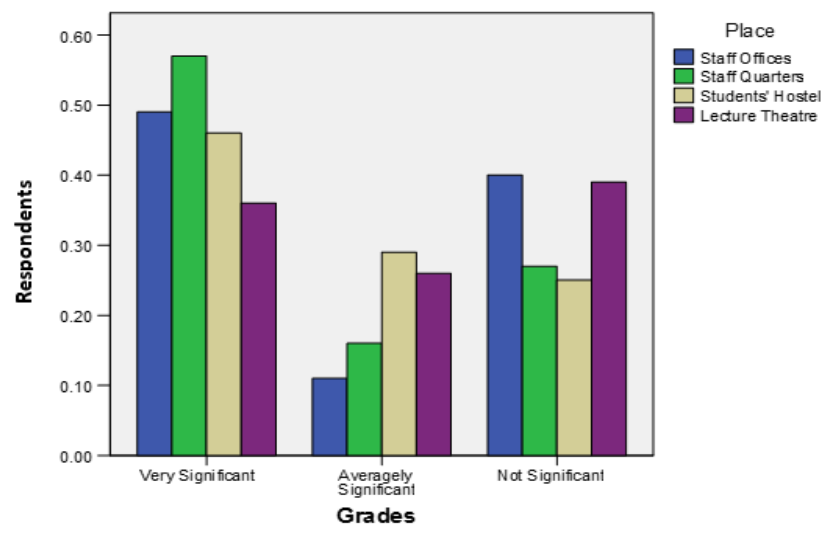

Figure 10: Responses on change of government

independent of the different University buildings) was rejected. Thus, the results reveal that the respondent responses are dependent of the different University buildings for all the factors considered in this research. This implies that all the responses are exclusive and they depend on the particular building being assessed. 
Table 1: Results of test of independence of the respondent responses

\begin{tabular}{|c|c|c|c|c|c|c|c|c|c|c|}
\hline \multirow{2}{*}{$\begin{array}{l}\text { Statistical } \\
\text { Test of } \\
\text { Independe } \\
\text { nce } \\
\end{array}$} & \multicolumn{10}{|c|}{ Factors affecting maintenance work at the University of llorin } \\
\hline & $\begin{array}{l}\text { Lack of } \\
\text { maintenan } \\
\text { ce policy }\end{array}$ & $\begin{array}{l}\text { Inadequat } \\
e \\
\text { provision } \\
\text { of funds } \\
\text { for } \\
\text { maintenan } \\
\text { ce }\end{array}$ & $\begin{array}{l}\text { Lack of } \\
\text { experienc } \\
\text { ed and } \\
\text { well- } \\
\text { trained } \\
\text { building } \\
\text { maintenan } \\
\text { ce } \\
\text { Engineer }\end{array}$ & $\begin{array}{l}\text { overcrowdi } \\
\text { ng }\end{array}$ & $\begin{array}{l}\text { Lack of } \\
\text { timely } \\
\text { response } \\
\text { to } \\
\text { maintenan } \\
\text { ce request }\end{array}$ & $\begin{array}{l}\text { Poor } \\
\text { maintenan } \\
\text { ce work } \\
\text { done by } \\
\text { the } \\
\text { maintenan } \\
\text { ce unit of } \\
\text { the } \\
\text { institution }\end{array}$ & $\begin{array}{l}\text { Corrupti } \\
\text { on }\end{array}$ & $\begin{array}{l}\text { Misuse } \\
\text { of } \\
\text { facilities } \\
\text { by } \\
\text { occupan } \\
\text { ts }\end{array}$ & $\begin{array}{c}\text { poor } \\
\text { architectu } \\
\text { ral design }\end{array}$ & $\begin{array}{l}\text { Change } \\
\text { of } \\
\text { governm } \\
\text { ent }\end{array}$ \\
\hline Chi- Square & 48.986 & 34.472 & 56.435 & 79.283 & 67.437 & 58.126 & 68.581 & 24.652 & 23.268 & 10.718 \\
\hline P-Value & $<0.001$ & $<0.0001$ & $<0.0001$ & $<0.0001$ & $<0.0001$ & $<0.0001$ & $<0.0001$ & $<0.0001$ & 0.001 & $<0.097$ \\
\hline
\end{tabular}

\section{CONCLUSION AND RECOMMENDATIONS}

The conclusions drawn from this research are:

1. Students who occupy the hostels and use the University lecture theatres perceive that lack of maintenance policy, inadequate provision of funds, insufficient well-trained building maintenance Engineers, overcrowding, untimely response to maintenance requests, poor maintenance work done, corruption, misuse of facilities by occupants, poor architectural design and change of government, all affect significantly the maintenance practice in the University of Ilorin.

2. The University staff believe that corruption and change of government significantly affect maintenance of their offices and staff quarters.

3. It is recommended that good maintenance policies devoid of corruption should be drawn by the University to ensure constant and regular maintenance of the infrastructures. Adequate funding should also be provided for maintenance. Regular training should be given to the staff of the Works Department to improve on their maintenance skills.

\section{REFERENCES}

[1] P. O. Akadiri, E. A. Chinyio, and P. O. Olomolaiye, "Design of A Sustainable Building: A Conceptual Framework for Implementing Sustainability in the Building Sector," Buildings, vol. 2, no. 2, pp. 126152, 2012.

[2] P. J. Cobbinah, "Maintenance of buildings of public institutions in Ghana. Case study of selected institutions in the Ashanti region of Ghana," Kwame Nkrumah University of Science and Technology, Kumasi, 2010.

[3] O. O. Ugwu, C. C. Okafor, and C. U. Nwoji,
"Assessment of building maintenance in Nigerian university system: a case study of University of Nigeria, Nsukka," Niger. J. Technol., vol. 37, no. 1, pp. 44-52, 2018.

[4] O. A. Adenuga, "Labour Composition for Maintenance Works in Public Hospital Built Environment in South-west, Nigeria," J. Build. Perform., vol. 1, no. 1, pp. 83-97, 2010.

[5] S. O. Oyenuga, O. E. Akinsola, and P. O. Hussaini, "Maintenance of University Facilities in Developing Country: Case study of Lagos State University Ojo Nigeria," Mediterr. J. Soc. Sci., vol. 3, no. 11, pp. 69-75, 2012.

[6] O. A. Lateef, M. F. Khamidi, and A. Idrus, "Building Maintenance Management in Malaysian University campuses: A case Study," Australas. J. Constr. Econ. Build., vol. 1, no. 2, pp. 76-89, 2010.

[7] S. O. B. Olanrewaju and O. S. Anifowose, "The challenges of building maintenance in Nigeria: (A Case Study of Ekiti State)," Eur. J. Educ. Dev. Psychol., vol. 3, no. 2, pp. 30-39, 2015.

[8] S. N. Zubairu, "Maintenance of Government Office Buildings in Nigeria: a Post-occupancy Evaluation Approach," University of Lagos, Nigeria, 1999.

[9] A. Yusuf, "An Appraisal of Corporate Property Maintenance Practices in Lagos and Oyo State," J. Environ. Des. Manag., vol. 1, no. 1, pp. 121132, 1998.

[10] S. J. Odediran, O. A. Opatunji, and F. O. Eghenure, "Maintenance of Residential Buildings: Users' Practice in Nigeria," J. Emerg. Trends Econ. Manag. Sci., vol. 3, no. 3, pp. 261-265, 2012.

[11] S. O. Olatunji, D. O. Aghimien, A. E. Oke, and

Vol. 38, No. 2, July 2019 
T. Akinkunmi, "Assessment of Maintenance Management Culture of Tertiary Institutions in Nigeria," Civ. Environ. Res., vol. 8, no. 6, pp. 98105, 2016.

[12] O. A. Adenuga, "Maintenance management practices in public hospital built environment: Nigeria case study," J. Sustain. Dev. Africa, vol. 14, no. 1, pp. 185-201, 2012.

[13] E. C. Eke, S. Musa, T. O. Fashubaa, and J. O. Abass, "An Assessment of Maintenance Culture on Public Buildings in Nigeria (A Case Study of Osun State)," IOSR J. Mech. Civ. Eng., vol. 14, no. 5, pp. 53-57, 2017.

[14] I. Pukīte and I. Geipele, "Different Approaches to Building Management and Maintenance Meaning Explanation," Procedia Eng., vol. 172, pp. 905-912, 2017.

[15] BS 3811 (1993), Glossary of Terms in
Terotechnology. 1993.

[16] E. S. Ojara, "The Challenges of Housing Maintenance in Nigeria," The Federal Polytechnic, Ado Ekiti, Nigeria, 2013.

[17] I. F. Iyamu, K. Imasuen, and E. F. Osakue, "Analysis of Maintenance Culture in Public Primary and Secondary Schools in Edo State," Int. J. Vocat. Tech. Educ. Res., vol. 4, no. 2, pp. 23-30, 2018.

[18] N. O. B. Nurul and O. M. Md Azree, "General Building Defects: Causes, Symptoms and Remedial Work," Eur. J. Technol. Des., vol. 3, no. 1, pp. 4-17, 2014.

[19] R. Talib, A. G. Ahmad, N. Zakaria, and M. Z. Sulieman, "Assessment of Factors Affecting Building Maintenance and Defects of Public Buildings in Penang, Malaysia," Sci. Acad. Publ., vol. 4, no. 2, pp. 48-53, 2014.

\section{APPENDIX}

\section{KOWARA STATE UNTVERSITY, MALETE DEPARTMENT OF CIVIL R ENVIRONMENTAL FACULTY OF ENGINEERING E TECHNOLOGY}

\section{ASSESSMENT ON BUILDING MAINTENANCE IN THE UNIVERSITY OF ILORTN QUESTIONNIARE (UNIVERSTTY LECTURE ROOMS)}

\footnotetext{
The series of questions in this questionnaire are designed to obtain organizational response on maintenance of university buildings.

Please, answer the questions that follow by ticking the appropriate option (if provided) or writing unrestrictedly for open-ended questions. Please answer all questions freely but objectively.

The information is for academic purposes only and will be treated with the strictest confidentiality.

Thenk You
}

Maintemance of University lecture rooms to be answered by the students using these lecture rooms.

1. How can you describs the condition of the lecture room foundation? (a) Cracks developed

(b) Weak (c) In good condition.

2. How can you describe the condition of the roof? (a) Leaking (b) Rusty (c) Partly ripped off.

3. How can you describe the condition of the floor? (a) Cracks developed (b) peeled off (c) In good condition.

4. How can you describe the condition of the wall? (a) Partially broken down (b) Cracks developed (c) peeled off (d) Bent (e) In good condition.

5. How can you describe the painting condition? (a) No painting (b) Worn out painting (c) dirty (d) In good condition.

6. How can you describe the condition of the windows? (a) Broken down (b) partially broken down (c) In good condition.

7. How can you describe the conditions of the doors? (a) broken down (b) partially broken down (c) In good condition.

B. How can you describe the condition of the electrical installations? (a) partially functioning (b) completely broken down (c) In good condition. 
9. How can you describe the condition of plumbing/water pipe? (a) Leaking (b) partially broken down (c) Completely broken down (d) In good condition.

10. What type of toilet facility do you use? (a) Water System (b) pit latrine, if any other, please specify

11. Are the toilet facility (a) Leaking (b) partially broken down (c) completely broken down (d) In good condition?

12. How can you describe the condition of your sewage system? (a) Leaking (b) broken down (c) partially broken down (d) In good condition.

Below are some of the major problems/factors that affect building maintenance. In your opinion kindly rate each of these selected factors in terms of their weight as they affect University building maintenance in Nigeria. The weights (on a Likert Scale of 1-3) are enclosed in brackets.

Your views on factors affecting the maintenance of the University building

S/N Factors $\quad$ very Significant (3) Averagely Significant (2) Not Significant (1)
1. Lack of maintenance policy
2. Inadequate provision of funds
for maintenance
3. Lack of experienced and well
trained building maintenance
Engineer
4. Overcrowding
5. Lack of timely response to
maintenance request
6. Poor maintenance work done
by the maintenance unit of the
institution
7. Corruption
9. Misuse of facilities by occupants
design architectural/structural

